\title{
Enjolras Vampré and the character of Les Misérables
}

\author{
Enjolras Vampré e o personagem de Les Misérables \\ Alex Tiburtino MEIRA', Gustavo Leite FRANKLIN²,3, Maria Luísa Pacífico Brandão MEIRA4', Isabella Araújo \\ MOTA ${ }^{5}$, Egberto Reis BARBOSA ${ }^{6}$, Hélio Afonso Ghizoni TEIVE²
}

\begin{abstract}
Enjolras Vampré (1885-1938) was one of the pioneering neurologists in Brazil whose name is a tribute to one of the characters of the book Les Misérables (1862), written by Victor Hugo (1802-1885). In this article, the authors point out evidence that the coincident names were not just a matter of homage, and even more so, the life of Dr. Enjolras had many similarities with the interesting character.
\end{abstract}

Keywords: History of Medicine; Neurology; Literature; Faculty.

RESUMO

Enjolras Vampré (1885-1938) foi um dos neurologistas pioneiros no Brasil cujo nome é uma homenagem a um dos personagens do livro Les Misérables (1862), escrito por Victor Hugo (1802-1885). Neste artigo, os autores apontam evidências de que os nomes coincidentes não são apenas uma questão de homenagem, mas ainda mais, a vida de Dr. Enjolras teve muitas outras semelhanças com o interessante personagem.

Palavras-chave: História da Medicina; Neurologia; Literatura; Docentes.

\section{INTRODUCTION}

Les Misérables, the masterpiece of the French writer Victor-Marie Hugo (1802 - 1885; Figure 1A)', was a five-volume book first published in $1862^{2}$. The romance, illustrated by Émille Bayard, addresses political and social issues in the $19^{\text {th }}$ century in France: injustice, poverty and social inequality ${ }^{2,3}$. Enjolras (Figure 1B and $1 \mathrm{C}$ ) is one of the main characters on the romance ${ }^{2}$.

Enjolras Vampré (Figure 2) was one of the first and most important physicians in the establish ment of neurology as a medical specialty in Brazil ${ }^{4}$. His parents paid tribute to the character of Victor Hugo's romance (Vampré YF, personal communication on January 17, 2021) $)^{5}$. The authors make a parallel between Dr. Enjolras Vampré and his homonym in Les Misérables.

\section{DR. ENJOLRAS VAMPRÉ}

Dr. Fabrício Carneiro Tupinambá Vampré and Mathilde de Andrade Vampré gave birth to their first of seven children, whom they named Enjolras Vampré (Figure 2A), on July $4^{\text {th }}$, 1885, in the city of Laranjeiras, Sergipe ${ }^{4}$. The chosen name, a very unusual name in Brazil, was a tribute to the character of Les Misérables 5 . One year later, the family moved to São Paulo. He graduated in Medicine in 1908, at the Faculty of Medicine of Bahia, where he did an internship at the chair of Psychiatry and Nervous Diseases, under Dr. Luiz Pinto Carvalho ${ }^{6}$. His engagement, remarkable grades and successful defense of his doctoral thesis into "Considerations about nervous and mental disturbances in the bubonic plague", which was approved with honor, took his portrait to the pantheon of that Faculty. He went to Europe twice: the first, as a

\footnotetext{
${ }^{1}$ Universidade Federal da Paraíba, Departamento de Medicina Interna, João Pessoa PB, Brazil.

${ }^{2}$ Pontifícia Universidade Católica, Departamento de Medicina Interna, Curitiba PR, Brazil.

${ }^{3}$ União das Instituições Educacionais de São Paulo, Centro Universitário, Cabedelo PB, Brazil.

«Universidade Federal do Paraná, Hospital de Clínicas, Departamento de Medicina Interna, Unidade de Distúrbios do Movimento, Curitiba PR, Brazil.

${ }^{5}$ Hospital Universitário Lauro Wanderley, João Pessoa PB, Brazil.

${ }^{6}$ Universidade de São Paulo, Departamento de Neurologia, Centro de Distúrbios do Movimento, São Paulo SP, Brazil.

ATM (D) https://orcid.org/0000-0002-6685-7491; GLF (ID) https://orcid.org/0000-0002-0207-3671; MLPBM (DD https://orcid.org/0000-0002-2916-6165;

IAM (iD https://orcid.org/0000-0003-1147-7894; ERB (iD) https://orcid.org/0000-0002-6996-9130; HAGT (D) https://orcid.org/0000-0003-2305-1073

Correspondence:Alex Tiburtino Meira; Email:alex.m.meira@gmail.com.

Conflict of interest: There is no conflicts of interest to declare.
}

Authors' contributions: ATM: conceptualization, data curation, formal analysis, investigation, methodology, resources, supervision, validation, visualization, writing-original draft, writing-review and editing; GLF, MLPBM, IAM, ERB, HAGT: formal analysis, methodology, project administration, validation, visualization, writing-review and editing.

Received on February 28, 2021; Received in its final form on March 30, 2021; Accepted on April 12, 2021. 


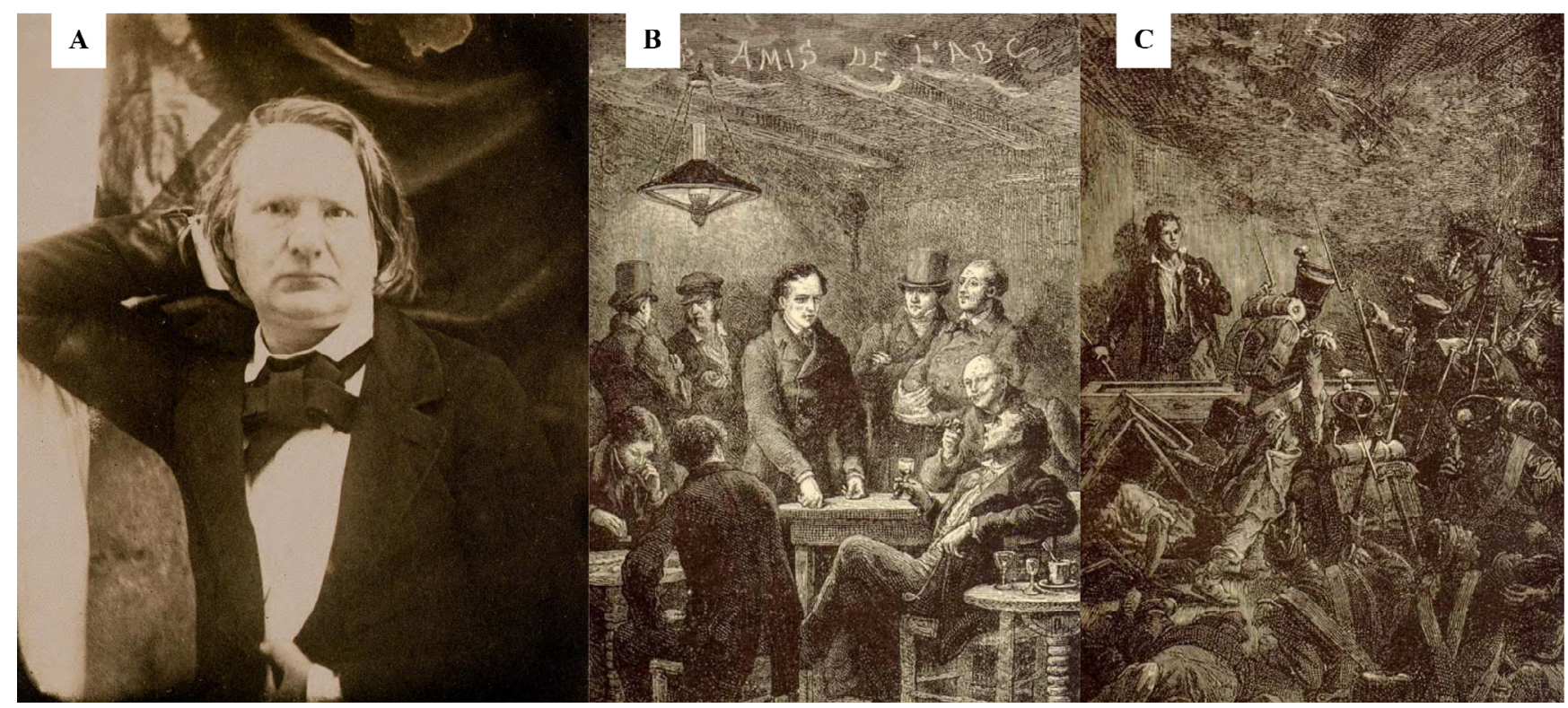

Figure 1. Victor Hugo and Les Misérables. 1A. Victor Hugo, in 1853 (February 26, 1802, Besançon, France - May 22, 1885, Paris, France); 1B. Enjolras leading the Amis de l'ABC 1C. Enjolras is cornered and executed by the soldiers (B and C: Les Misérables, by Victor Hugo, illustration by Émille Bayard, 1862). Public domain.
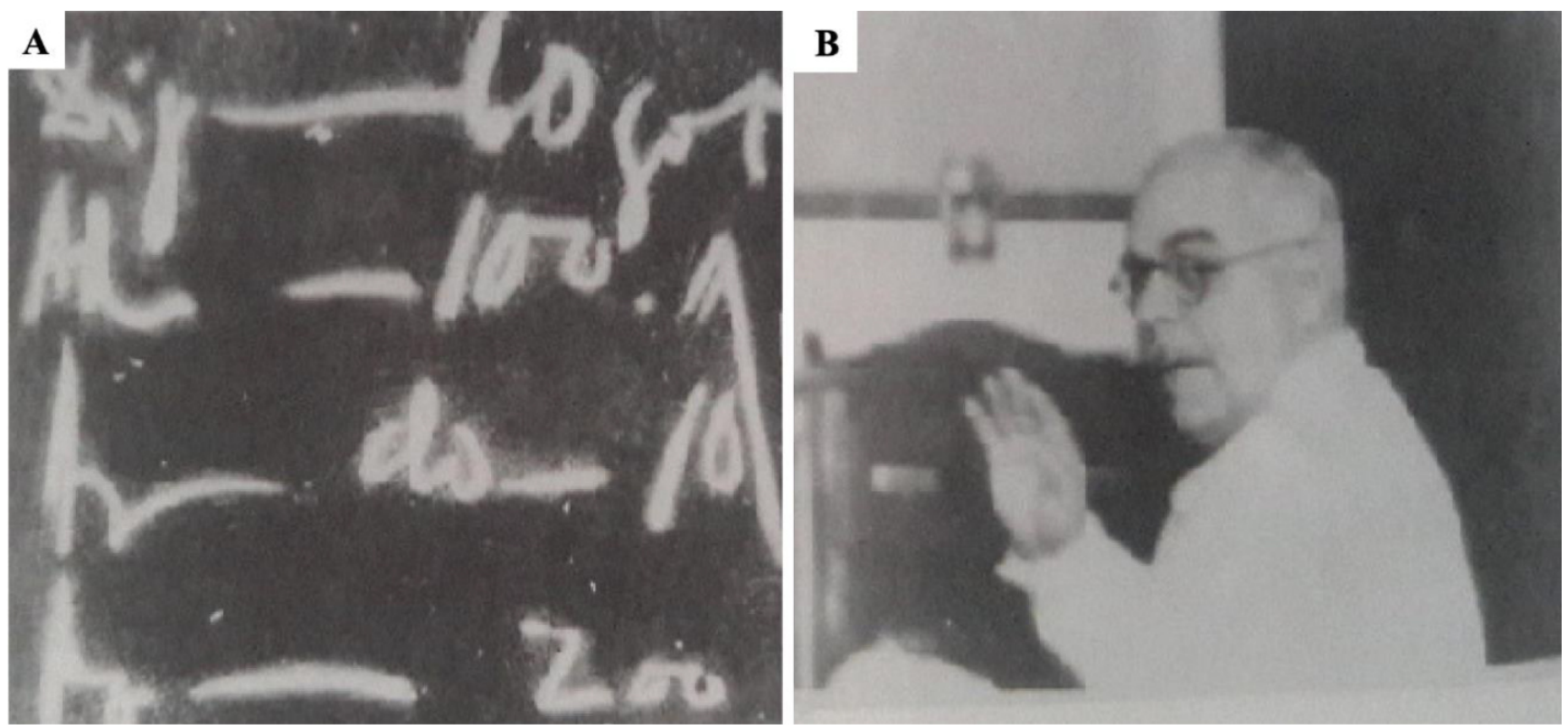

Figure 2. Dr. Enjolras Vampré during his last class, in which he suffered a hemorrhagic stroke (May 13, 1938): A. the chalkboard was risked during the attack; B. beginning of the class in which the professor suffered a hemorrhagic stroke. ${ }^{12}$

prize Professor Manoel Victorino Pereira gave him in 1910 for his thesis ${ }^{7}$, and the second, in the memory of the centenary of Charcot's birthday (1925). He took classes with Babinski, Dejerine, Bertrand, Foix and Guillain, in France, and Daldorf, Wuhlgarten, Herxberg and Brech, in Germany ${ }^{4,7}$.

Dr. Enjolras Vampré returned to São Paulo and worked at the Juquerí Hospital and at Instituto Paulista 8 . He became Professor in 1925, teaching Clinical Psychiatric and Neuriatric at the Faculty of Medicine of the University of São Paulo (FMUSP) from 1925 to 1935, succeeding Franco da Rocha?. At the end of 1935, after his insistence for a public contest, the examining commission witnessed him publicly attesting his didactic and scientific capabilities, as the only registered candidate ${ }^{9}$. He assumed the chair of Neurology at FMUSP on December 24, 19357, which was celebrated with a lunch with the most prominent authorities ${ }^{10}$. He is recognized as Father of neurology in the state of São Paulo, and also as one of the major physicians of the $20^{\text {th }}$ century in Sergipe ${ }^{11,12}$.

He was married to Marietta Pederneiras Vampré. The couple had one son and one daughter, Paulo and Marina Pederneiras Vampré. In family life, he was known as a humble and respected man, who studied every day and had the 
walls of his home office covered with books. His son Paulo Pederneiras Vampré, which was also a physician, donated the professor's collection (books, editions of Révue Neurologique and doctoral theses from Paris) to the library of Clinical Neurology at FMUSP, that bears his name (Vampré YF, personal communication on January 17,2021$)^{5,7}$.

His ephemeral academic life is highlighted by encouraging disciples, by writing scientific articles and by participating in societies $^{7,8}$. Adherbal Tolosa, Paulino Longo, Oswaldo Lange and Fausto Guener were his main disciples. They had remarkable achievements: 1. succeeding Enjolras; 2. establishing the chair and the service of Neurology at the Paulista School of Medicine (1933), having Fausto Guerner as the first professor of Neurology; 3. creating the journal "Arquivos de NeuroPsiquiatria" (1943); and 4. founding the Brazilian Academy of Neurology $(1962)^{7,8,13,14}$. Enjolras Vampré published more than 120 works, proving his profound knowledge in the nervous system (check references 10 and 17) , $^{6,15}$.

He founded and participated in several societies, academies and sections, including in Buenos Aires and Paris, not only as member, but also as president, vice-president, treasurer, honorary member and corresponding partner. He is also the chair patron in the National Academy of Medicine (Chair 49), Academy of Medicine of São Paulo (Chair 54) and Sergipe (Chair 11); and Paulista Academy of Psychology (Chair 38) $)^{4,15}$.

At the peak of his academic accomplishments, during a class on the "malariotherapy for neurosyphilis", he suffered a hemorrhagic stroke, on May 13, 1938 (Figure 2A and B) ${ }^{6}$, and died on May 17, 1938, when he was 52-years-old ${ }^{6,16}$.

\section{SIMILARITIES BETWEEN A FACULTY MEMBER AND A FICTIONAL CHARACTER}

Enjolras Vampré had an ephemeral but prominent academic life. He was well-known for his didactic capabilities and his practical approach ${ }^{8}$. Enjolras (no surname, born around 1810; Figure 2B), one of the main characters of Victor Hugo's novel, was around 22 years old ${ }^{17}$. The beautiful only child of a bourgeois family was an idealistic law student, who showed up as the head of the group Amis de l'ABC ("Friends of ABC"; Figure 1B) - in French, the pronunciation ah-baesae sounds like abaissé (meaning "demoted", "diminished", "worthless") 2,18. His oratory and his mirroring in the abaissé made him a leader ${ }^{23}$. France is another link between both Enjolras: Professor Vampré visited several services in the country of the character ${ }^{7}$.

Victor Hugo's character had the revolutionary sentiment as his only passion, giving up on materialism and romanticism $^{2,17}$. The fictional Enjolras had also his followers ${ }^{2}$. Both Enjolras shared the stripping and the sacrifice, which returns to their names, Enjolras, which phonetically has the word ange (/ ãz / angel). Example to others, they encouraged their disciples and let a legacy for them, which echoes in the history of Brazilian Neurology and the fictional French Revolution.

In June 1832, the death of General Lamarck, a hero of the Napoleonic wars, started the rebellion. In Saint-Denis street, a barricade was formed by the insurgents, where they were executed one-by-one. Enjolras was cornered and executed by 12 troop gunners (Figure 1C). The death of Enjolras concluded his self-sacrifice for the revolutionary cause ${ }^{2}$. The premature death of both Enjolras occurred in their main environment and at the peak of their productions: the classes of Neurology (the Professor) and the rebellion of the French insurgents (the character).

In conclusion, Professor Enjolras Vamprës name was a tribute paid by his parents to the homonym character of Victor Hugo's masterpiece. There were some similarities between Enjolras, the Professor, one of the most prominent professors of Neurology in Brazil, and the fictional character of Les Misérables.

\section{ACKNOWLEDGEMENTS}

The authors thank the family Vampré, in the names of Yolanda Franco Vampré (granddaughter) and Pedro Goldenstein (husband of a great granddaughter), who cooperated incredibly with this article.

\section{REFERENCES}

\footnotetext{
1. Graham R. Victor Hugo. London: Pan MacMillan; 1997.

2. Hugo V. Les misérables. Paris: A. Lacroix, Verboeckhoven \& Ce; 1862.

3. Pereira MJ. Memória e identidade do povo no romance socio-histórico Les misérables: a personagem Enjolras. Palimpsesto. 2018;17(27):205-22. https://doi.org/10.12957/ palimpsesto.2018.38382

4. Costa HCBVA. Resgatando a memória dos Patronos Enjolras Vampré Cadeira 38. Bol Acad Paul Psicol. 2009 Dec;77(2-9):227-32.

5. Octávio LOR. Elos de uma corrente: seguidos de novos elos. Rio de Janeiro: Civilização brasileira; 1994.300p.

6. Neves AC. O emergir do corpo neurológico no corpo paulista: Neurologia, Psiquiatria e Psicologia em São Paulo a partir dos
}

periódicos médicos paulistas (1889-1936) [PhD]. [São Paulo (SP)]: Universidade de São Paulo; 2008. 508p.

7. Canelas HM. Centenário de Enjolras Vampré. Arq Neuropsiquiatr. 1985 Dec;43(4):343-6. https://doi.org/10.1590/S0004$282 \times 1985000400001$

8. Lange O. In memoriam professor Enjolras Vampré. Arq Neuropsiquiatr. 1943 Jun;1(1):3-5. https://doi.org/10.1590/S0004282X1943000100001

9. Faculdade de Medicina. Jornal Correio Paulistano. 1935 Dec 14; Sect. Geral:4.

10. Prof. Enjolras Vampré. Jornal O Estado de São Paulo. 1935 Dec 27; Sect. Geral:4. 
11. Silva PSN. Médicos por formação, docentes em ação: o perfil profissional e a formação do campo médico em Sergipe (1966-1973) [PhD]. [São Cristóvão (SE)]: Universidade Federal de Sergipe; 2018. $251 \mathrm{p}$.

12. Meira AT, Betini BG, Cardoso F, Gomes MM, Barbosa ER, Prado RCP, et al. First stages towards the establishment of Brazilian neurology faculties. Arq Neuropsiquiatr. 2019 Dec;77(12):888-95. https://doi. org/10.1590/0004-282X20190147

13. Franco da Rocha e Enjolras Vampré: nomes saudosos da Clínica Neurológica. Jornal O Estado de São Paulo. 1963 Apr 28; Sect. Geral:23.

14. Spina-França A. Os sessenta anos de Arquivos de Neuro-Psiquiatria. Arq Neuropsiquiatr. 2002 Dec;60(4):1061-2. https://doi.org/10.1590/ S0004-282X2002000600041
15. Begliomini H [Internet]. Enjolras Vampré. São Paulo: Academia de Medicina de São Paulo; [cited ano mês dia] 3p. Available from: https://www.academiamedicinasaopaulo.org.br/?pg=download\&aca $\mathrm{o}=1 \& \mathrm{id}=49 \&$ biografia $=$ Enjolras\%20Vampr\%E9\#gsc.tab $=0$

16. Longo PW. Prof. Enjolras Vampré. Rev Med. 1938;22(65):83-91. https://doi.org/10.11606/issn.1679-9836.v22i65p83-91

17. Pereira MJ. As personagens Myriel, Enjolras, Jean Valjean e Javert, em Les Misérables, de Victor Hugo: reações à concepção de justiça legalista [Master]. [Araraquara (SP)]: Universidade Estadual Paulista "Júlio de Mesquita Filho"; 2020. 194p.

18. Trouillez É, Dehais A. Le Robert micro poche: dictionnaire d'apprentissage du français. Paris: Dictionnaires Le Robert; 2013. $1657 p$. 